Garcia, J., Cerdeira, R., Tavares, N., Coelho, L.M.R., Kumar, P., Carvalho, M.G., 2013. Influence of virtual changes in building configurations of a real street canyon on the dispersion of $\mathrm{PM}_{10}$. Urban Climate 5, 68-81. http://dx.doi.org/10.1016/j.uclim.2013.08.002

\title{
Influence of virtual changes in building configurations of a real street canyon on the dispersion of $\mathbf{P M}_{10}$
}

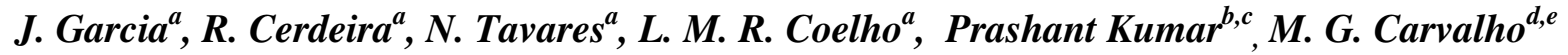 \\ ${ }^{a}$ Escola Superior de Tecnologia de Setúbal, Instituto Politécnico (ESTSetubal-IPS), Setúbal, \\ Portugal \\ ${ }^{\mathrm{b}}$ Department of Civil and Environmental Engineering, Faculty of Engineering and Physical \\ Science (FEPS), University of Surrey, GU2 7XH, United Kingdom \\ ${ }^{\mathrm{c}}$ Environmental Flow (EnFlo) Research Centre, FEPS, University of Surrey, GU2 7XH, United \\ Kingdom \\ ${ }^{\mathrm{d}}$ Instituto Superior Técnico (IST), Lisbon, Portugal, \\ ${ }^{\mathrm{e}}$ Member of the European Parliament, Brussels, Belgium
}

\begin{abstract}
Four geometrical configurations of a real street canyon in Barreiro city (Portugal) are considered to study their influence on the dispersion of $\mathrm{PM}_{10}$. These configurations include actual architectural layout of the street (Option 1), and three virtual cases (Options 1-3). Option 2 includes the modification of real geometry by including $4 \mathrm{~m}$ gaps between the buildings situated on the southern part of the street canyon. Option 3 considers $6 \mathrm{~m}$ gaps between buildings as opposed to $4 \mathrm{~m}$ gaps in Option 2. Option 4 assumes the same height for all buildings on the southern part of the street canyon, with no gaps between buildings. Computational fluid dynamics code (CFD), FLUENT, is used to simulate the detailed flow and turbulence characteristics in three-dimensional domain of chosen street canyon, together with the $\mathrm{PM}_{10}$ dispersion for both the summer and winter seasons. The modelled $\mathrm{PM}_{10}$ concentrations were then compared with the measured data at seven different locations in the street canyon. Our results indicate up to $23 \%$ lower $\mathrm{PM}_{10}$ concentrations at $1.5 \mathrm{~m}$ above the road level during the along-canyon wind direction due to the channelling of flow, compared with those observed during the cross-canyon wind direction. Detailed inspection of the results obtained from the Options 1-3 indicated that the spacing between the buildings tend to increase particle dilution during the crosscanyon winds, resulting in up to 20, and $22 \%$ reduced concentrations for options 2 , and 3 respectively, compared with the actual configuration (Option 1). The largest improvement $(\sim 7 \%)$ in the $\mathrm{PM}_{10}$ concentrations was given by Option 2, while other options showed modest changes. Possible reasons for these changes under varying meteorological conditions are explained in the context of changing building configurations and their implications in city planning.
\end{abstract}

Key words: $P M_{10}$ dispersion; $C F D$ code Fluent; Barreiro street canyon; Real and virtual building configurations, Traffic emissions

\section{Research highlights:}

- $\mathrm{PM}_{10}$ simulations in a street canyon are carried out using a CFD code, FLUENT

- Influence of different building configurations on peak $\mathrm{PM}_{10}$ levels is studied

- Modelled CFD results are compared with the measured $\mathrm{PM}_{10}$

- Virtual opening in buildings reduced peak $\mathrm{PM}_{10}$ concentrations

- Building configurations found to be important for controlling $\mathrm{PM}_{10}$ concentrations

\section{INTRODUCTION}

Planning of urban buildings is important because of its influence on the indoor and outdoor air quality, public health, and sustainable development (EEA, 2011; Kumar and Morawska, 2013). In particular, air quality in urban areas is getting attention, worldwide, due to its adverse impact on the health of city dwellers (Borrego et al 2004; Kumar et al., 2011a). In the range of air pollutants, particular attention has been paid to the particulate matter with 
Garcia, J., Cerdeira, R., Tavares, N., Coelho, L.M.R., Kumar, P., Carvalho, M.G., 2013. Influence of virtual changes in building configurations of a real street canyon on the dispersion of $\mathrm{PM}_{10}$. Urban Climate 5, 68-81. http://dx.doi.org/10.1016/j.uclim.2013.08.002

less than 10 and $2.5 \mu \mathrm{m}$ in diameter (i.e., $\mathrm{PM}_{10}$ and $\mathrm{PM}_{2.5}$, respectively) (Martins et al., 2009; Amorim et al., 2010; Heal et al., 2012) and more recently to airborne nanoparticles (Kumar et al., 2011b; Kumar et al., 2010). Street canyons are considered as a hot spots where exposure levels can be very high due to the build-up of pollutant concentrations as a result of limited dispersion (Britter and Hanna, 2003; Kumar et al., 2008). Numerous epidemiological studies have focused on the $\mathrm{PM}_{10}$ and $\mathrm{PM}_{2.5}$ exposure and there are a certain evidences that short term exposure to high concentrations of $\mathrm{PM}_{10}$ can aggravate pulmonary diseases and influence paediatric asthma (Garcia et al., 2010). Likewise, long term exposure to high concentrations on $\mathrm{PM}_{10}$ may increase the risk of cardiovascular and pulmonary disease (WHO, 2004). Topography and urban obstructions such as buildings and other construction influence the atmospheric flow greatly (Britter and Hanna, 2003) and consequently the dispersion of pollutants arising from the vehicle exhausts (Kumar et al., 2011b). Pollutants in street canyons cannot be carried away by the wind easily since the buildings act as a barrier. This results in trapping of pollutants within the canyons (De Paul and Sheih, 1986) and raising their concentrations to high levels (Zhou et al, 2008). For instance, a recent study by Wang et al. (2010) studied the effect of building geometries in street canyons. They found that emissions from intensive traffic flows can raise the pollutant concentrations considerably, depending on the street canyon configuration and the type of flow regimes inside the canyon. Therefore, it is important from the decision makers' point of view to be acquainted with the influence of building density and geometry on the extent of air quality deterioration in urban street canyons.

With the improvement in computational power, dispersion modelling tools such as the computational fluid dynamics (CFD) are particularly useful for simulating the detailed wind and dispersion fields in urban areas that have complex building geometries. The use of CFD tools is complex and resource intensive, but these also provide an opportunity to simulate the complex effect of meteorology and building geometries (e.g. orientation and intensity). Despite the complexity of governing equations (Mochida et al, 2011), the continuous development of powerful numerical codes and implausible increases in hardware performances have made the CFD simulations attractive for complex urban geometries. Numerical simulations have been found to predict the flow and dispersion in urban street canyons fairly well (Sagrado et al., 2002). Vardoulakis et al. (2003) reviewed a number of air quality models for street canyons, including operational, Gaussian plume and CFD models. Their review reports that microscale models such as MIcroscale MOodel, MIMO (Ehrhard et al., 2000) and mesoscale model MEsoskaliges TRAnsport und Stroemungsmodell, METRAS (Schlunzen et al., 1996) are especially designed for street canyon applications. Considering the air quality in roadside environments, the review concluded that CFD has the advantage to reproduce the flow and concentration fields with a reasonable accuracy within urban canyons of any configuration, if the right input data and boundary conditions are supplied. Moreover, field measurements are equally important to complement and validate the modelled CFD results.

Latter, Holmes and Morawska (2006) reviewed various dispersion models (Box, Gaussian, Langrangian, Eularian) that are applied to both inert and reactive particles. They reported that the majority of commercial dispersion models do not make any specific treatment of particle dynamics and limit the calculations to particle mass concentrations (PMC). Also was highlighted that the comprehensive performance evaluation of many dispersion models remains an issue due the lack of required measurement data. A number of studies have also 
Garcia, J., Cerdeira, R., Tavares, N., Coelho, L.M.R., Kumar, P., Carvalho, M.G., 2013. Influence of virtual changes in building configurations of a real street canyon on the dispersion of $\mathrm{PM}_{10}$. Urban Climate 5, 68-81. http://dx.doi.org/10.1016/j.uclim.2013.08.002

compared the CFD simulated results with the measured data, showing under/over prediction of modelled PMCs and attributing these differences in results to the uncertainty in input data (Pospisil and Jicha, 2008; Santiago and Martin, 2008; Nikolova et al., 2011). For example, Kumar et al. (2009) studied the dispersion of inert nanoparticles in an urban street canyons using a CFD code FLUENT on a simplified canyon geometry, the Operational Street Pollution Model (OSPM) and the modified Box model. The modelled concentrations compared well (between a factor of 2 and 3) with the measured concentrations, suggesting that even a simplified approach can predict the concentrations as well as more complex models if the model inputs are chosen carefully.

In order to carry out parametric studies under different geometrical configurations and wind directions, an operational street canyon in Barreiro city (Portugal) is chosen together with the other three virtual scenarios that reflect modifications in real street canyons (see Section 2.1). The CFD code, FLUENT, is used on three-dimensional site geometry to simulate the influence of the fluid flow on $\mathrm{PM}_{10}$ concentrations in the street canyon; the modeled results are then compared with measured $\mathrm{PM}_{10}$ concentrations. The approach allowed studying the influence of different building configuration, comparison of results obtained in virtual geometries with the actual configuration, and identifying the specific hot spots. The key objectives of this work are to identify the most favourable street configuration for pollutant dispersion, particularly $\mathrm{PM}_{10}$, in different geometrical configurations and meteorological conditions. The findings can assist urban planners to propose environmental friendly design of new housing projects, favouring better air quality.

\section{METHODOLOGY}

\subsection{SITE DESCRIPTION}

The studied site, Avenida do Bocage street in Barreiro city, is about $40 \mathrm{~km}$ south of Lisbon (Fig. 1). Barreiro is a relatively small city with about $34 \mathrm{~km}^{2}$ surface area and 80,000 inhabitants. Several industrial units such as the combined heat and oil fired power stations, chemical industrial complex, and acrylic fibres factory are near the city centre. Typical city traffic involves buses, heavy duty vehicles (HDVs), light duty vehicles (LDVs; including cars and taxis), and motorcycles. Ground surface of Barreiro is flat and the highest ground level point of the city is at $\sim 10 \mathrm{~m}$ above the sea level. This street is an important road - this connects the city centre of Barreiro with a main motorway to the capital of Portugal, Lisbon. The street is $\sim 263 \mathrm{~m}$ long and has a width of $\sim 20 \mathrm{~m}$ between the both sides of buildings. Heights of the buildings on both side of the street vary between 7 and $39 \mathrm{~m}$. As shown in Fig. $1 \mathrm{a}$, the street canyon runs approximately between east and west directions. A sample study was conducted for counting traffic volumes during the $\mathrm{PM}_{10}$ measurement campaigns (see Section 2.5). A total of $3794 \mathrm{veh} \mathrm{h}^{-1}$ was counted. These included LDVs, HDVs, buses, cars and motorcycles as $95.8,1.6,2.0$ and $0.6 \%$ of total vehicles, respectively.
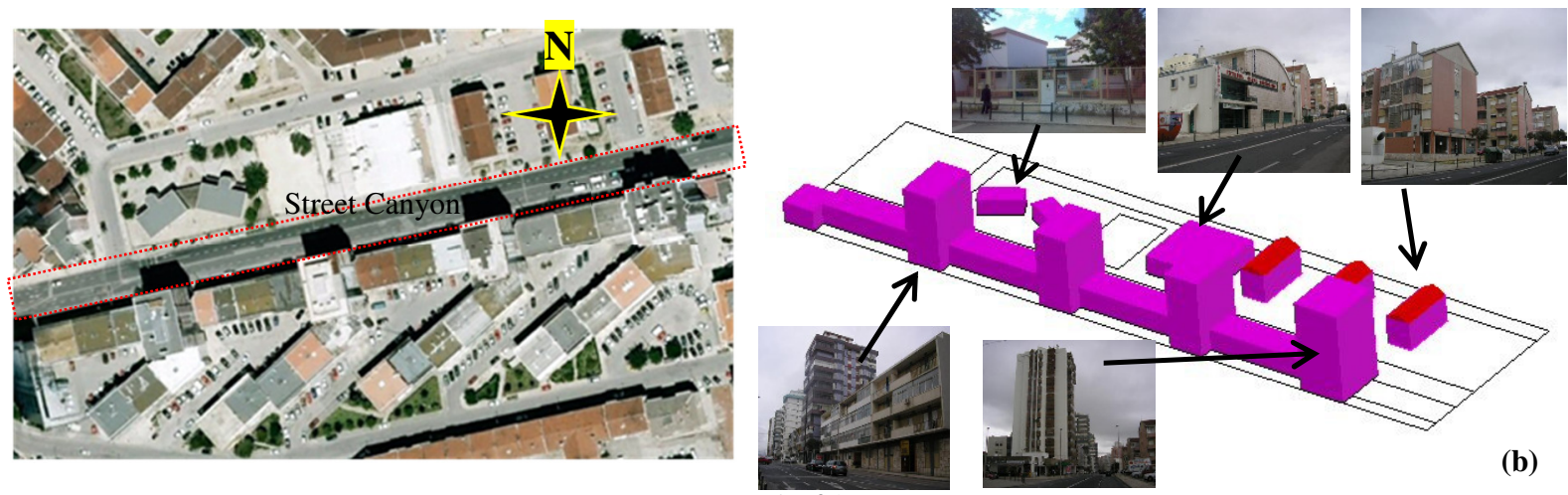
Garcia, J., Cerdeira, R., Tavares, N., Coelho, L.M.R., Kumar, P., Carvalho, M.G., 2013. Influence of virtual changes in building configurations of a real street canyon on the dispersion of $\mathrm{PM}_{10}$. Urban Climate 5, 68-81. http://dx.doi.org/10.1016/j.uclim.2013.08.002

(a)

Fig. 1. Schematic diagram of studied street canyon, Avenida do Bocage, showing: (a) aerial view of the street and its orientation, and (b) various snapshots of the canyon along with an idealised computational domain of the entire canyon.

\subsection{THE CFD MODEL, FLUENT}

The CFD model, Ansys FLUENT 12.0, was used to simulate flow and dispersion of $\mathrm{PM}_{10}$ in the selected street canyon. This multi-purpose commercial CFD tool has been widely used for this kind of application and comparison with their results with other dispersion models (Di Sabatino et al., 2008) or wind tunnel measurements (Awasthi and Chaudhry, 2009). The studied domain considered a safety distance to avoid interference of flow between the buildings and both the inlet and outlet domain boundaries. This safety distance was $5 H$ (where $H$ is the average height of buildings) from the domain inlet to the buildings location, $15 \mathrm{H}$ from buildings location to the outlet, and $4 \mathrm{H}$ from top of buildings (COST, 2007). The simulations were carried out for a total of four wind directions; one of which (West) represents the predominant wind directions for the studied area (see Section 2.5).

The simplified computational domain for the chosen street canyon has length, breadth and height as 715, 300 and $150 \mathrm{~m}$, respectively, for the westerly and easterly wind directions (see Fig. 2). A tetrahedral unstructured grid was used for the spatial discretisation of the computational domain, which was refined near the buildings. For the construction of the grid Ansys Workbench software (Ansys, 2009) was used. Due to the computational limitations, the smallest grid size was kept $1 \mathrm{~m}$ close to the walls of buildings. This grid size increased with the distance from the walls, using an expansion factor equal to 1.2. The domain included a total of 201354 cells and 37303 nodes for the west wind direction. For the winds from the north and south the domain has length, breadth and height as 491,524 and $150 \mathrm{~m}$, respectively. The number of cells and nodes remain same for all the domains. A mesh sensitivity analysis was made to verify the independence of the solution, following the COST 732 guidelines (COST, 2007), to confirm that the prediction result does not change significantly with different grid systems.
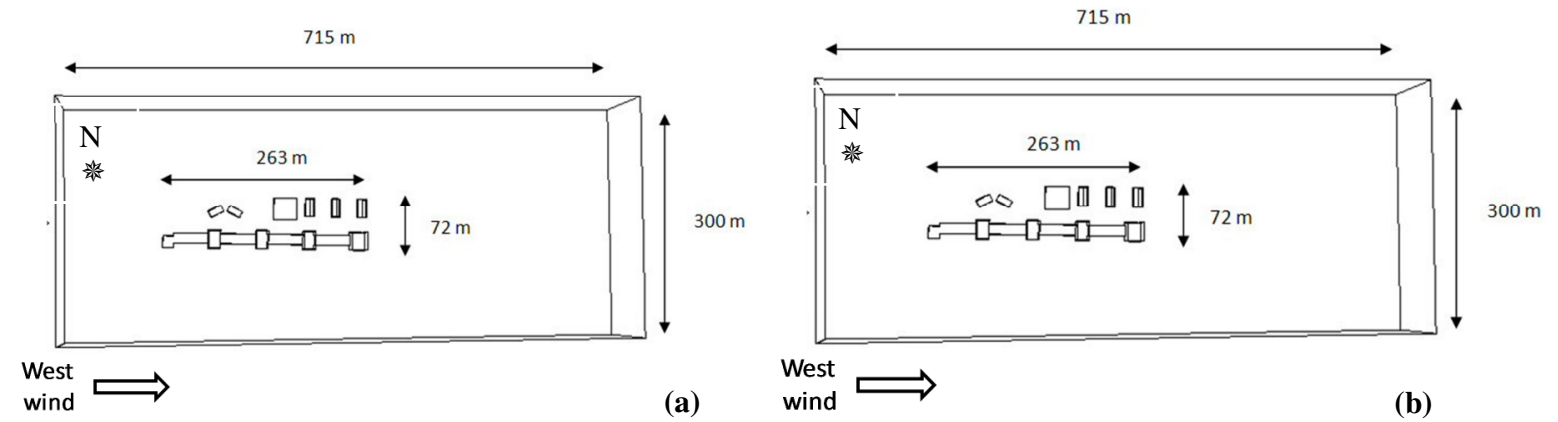

(b) 
Garcia, J., Cerdeira, R., Tavares, N., Coelho, L.M.R., Kumar, P., Carvalho, M.G., 2013. Influence of virtual changes in building configurations of a real street canyon on the dispersion of $\mathrm{PM}_{10}$. Urban Climate 5, 68-81. http://dx.doi.org/10.1016/j.uclim.2013.08.002

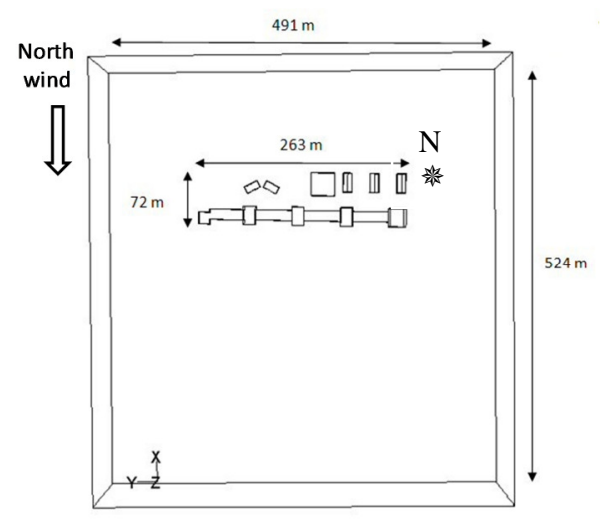

(c)

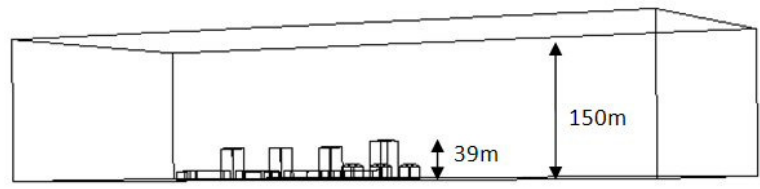

(e)

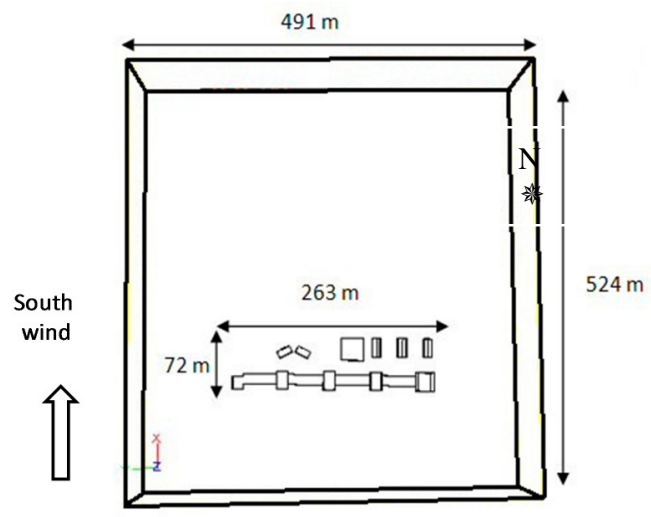

(d)

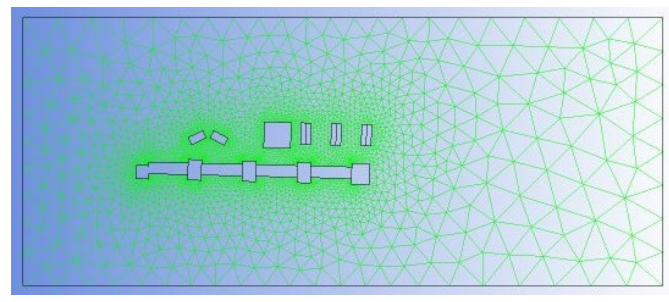

(f)

(Figures not to scale) Fig. 2. Schematic diagram showing (a) top plan, for wind from the west direction, (b) top plan for east direction, (c) top plan for north direction, (d) top plan for south direction, (e) side view of the domain, and (f) mesh resolution around buildings.

An Eulerian approach was applied for the simulation of 3D flow, assuming steady-state conditions. For the turbulence closure, a RNG k-e model was used that calculated 3D fields of wind, turbulent viscosity, pressure and turbulence. For the $\mathrm{PM}_{10}$ dispersion, a Lagrangian approach was used for the computation of the 3D concentration field. The dispersion model consists of a second phase of spherical particles in a Lagrangian frame of reference, dispersed in the continuous phase with coupling between the phases. The initial position, velocity and size of particles were introduced, and the stochastic tracking considered was the discrete random walk model. Atmospheric conditions were assumed as neutral. The RNG k-e turbulence model was adopted that provided an analytical formula for turbulent Prandtl numbers. At the inlet, a logarithmic vertical wind profile was adopted; this assumed a reference velocity as $10 \mathrm{~m} \mathrm{~s}^{-1}$ at $10 \mathrm{~m}$ height, based on the local measurement campaigns. The wind profile, turbulent kinetic energy, and turbulence dissipation rate was introduced as a user defined function (UDF) using the following formulation:

$$
U_{y}=\frac{u^{*}}{\kappa} \ln \left(\frac{y+y_{0}}{y_{0}}\right)
$$

Where $U_{\mathrm{y}}\left(\mathrm{m} \mathrm{s}^{-1}\right)$ is the wind velocity at height, $y ; \kappa(=0.42)$ is the Von Karman constant; $y_{0}$ (m) is the aerodynamic roughness length of the ground; $u^{*}\left(\mathrm{~m} \mathrm{~s}^{-1}\right)$ is the friction velocity (Richards and Hoxey, 1993). 
Garcia, J., Cerdeira, R., Tavares, N., Coelho, L.M.R., Kumar, P., Carvalho, M.G., 2013. Influence of virtual changes in building configurations of a real street canyon on the dispersion of $\mathrm{PM}_{10}$. Urban Climate 5, 68-81. http://dx.doi.org/10.1016/j.uclim.2013.08.002

$$
u^{*}=\frac{\kappa U_{10}}{\ln \left(\frac{10+y_{0}}{y_{0}}\right)}
$$

Where $U_{10}\left(\mathrm{~m} \mathrm{~s}^{-1}\right)$ is the wind velocity at $10 \mathrm{~m}$ height. The turbulent kinetic energy, $\varepsilon\left(\mathrm{m}^{2} \mathrm{~s}^{-2}\right)$, and turbulence dissipation rate, $k\left(\mathrm{~m}^{2} \mathrm{~s}^{-2}\right)$, at the inlet is estimated using:

$$
\varepsilon=\frac{u_{*}^{3}}{\kappa\left(y+y_{0}\right)} \quad \text { and } \quad k=3.33 u_{*}^{2}
$$

The $\mathrm{PM}_{10}$ emission rate in the street canyon was chosen as $1.82 \times 10^{-6} \mathrm{~kg} \mathrm{~s}^{-1}$. As described in Section 2.4, this source strength for local conditions was estimated using the ADMS-Urban model (CERC, 2006). Two line sources were added in the CFD domain, one for each lane, located at $0.1 \mathrm{~m}$ above the pavement level for simulating the height of the vehicles' exhaust pipe. A no-slip boundary condition was imposed at all solid surfaces i.e., the flow in the nearwall region was represented by the law-of-the-wall for mean velocity. A symmetry boundary was assumed at the top of the domain, assuming a zero flux of all the quantities across the horizontal plane.

\subsection{THE BUILDING CONFIGURATION SCENARIOUS}

Four building configuration scenarios were considered with the objective of studying the possibility of improvements in $\mathrm{PM}_{10}$ concentrations within this street canyon (Fig. 3). The first configuration (Option 1) corresponds to the actual architectural layout on both sides of the street (see Fig. 3a). The remaining three configurations (Options 2, 3 and 4') consisted 'virtual' minor alterations in the arrangement of buildings on the south side of the street. For instance, Option 2 considers $4 \mathrm{~m}$ gaps between the buildings along the left hand, southern, side of the street (Fig. 3b). Option 3 considered $6 \mathrm{~m}$ wide gaps as opposed to $4 \mathrm{~m}$ assumed in 'Option 2' (Fig. 3c). The last configuration, Option 4, considered the equal volume of total buildings, as in Option 1, but assumed a uniform geometry having: (i) identical height (i.e. 20 $\mathrm{m}$ ) on the both sides of building, and (ii) the same building width throughout (i.e. $261 \mathrm{~m}$ ) the street, with no gap between the buildings (Fig. 3d).
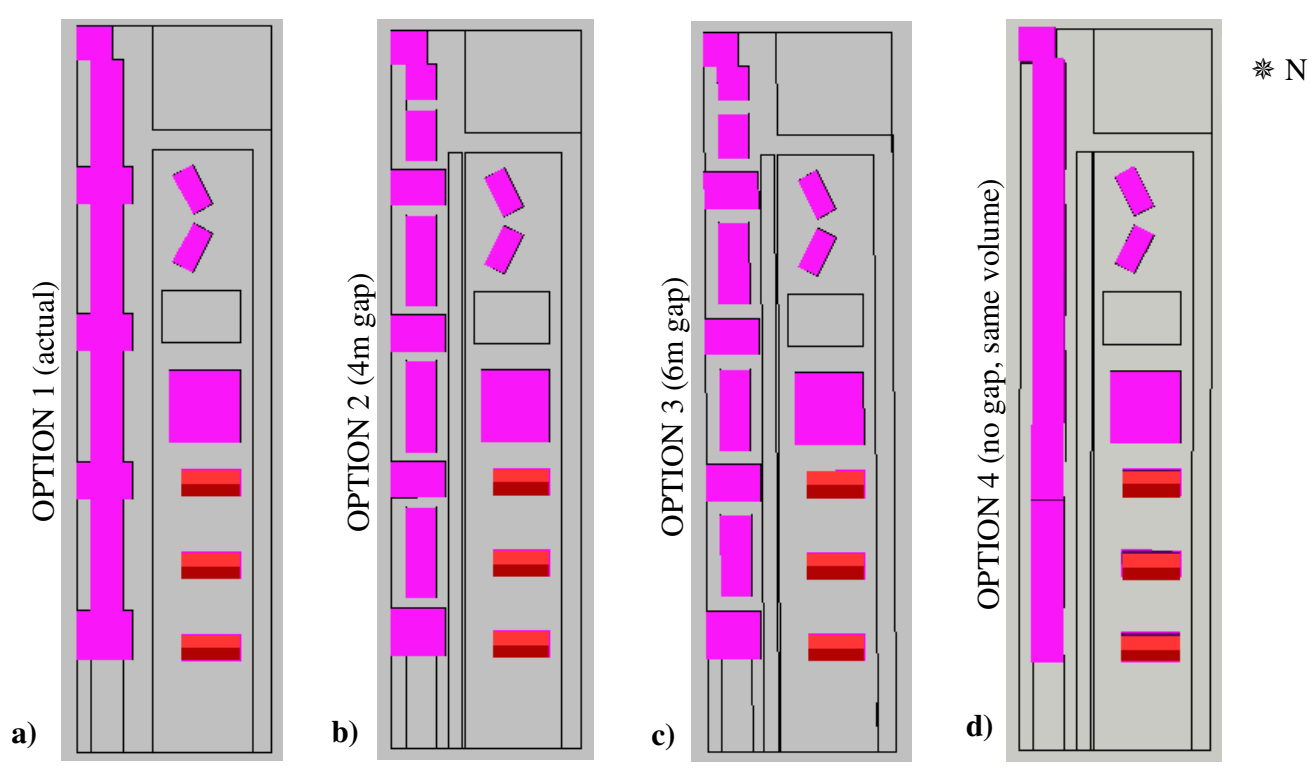

Page 6 of 17 
Garcia, J., Cerdeira, R., Tavares, N., Coelho, L.M.R., Kumar, P., Carvalho, M.G., 2013. Influence of virtual changes in building configurations of a real street canyon on the dispersion of $\mathrm{PM}_{10}$. Urban Climate 5, 68-81. http://dx.doi.org/10.1016/j.uclim.2013.08.002

Fig. 3. The four building configuration scenarios considered for simulations: (a) the actual configuration (Option 1), (b) assuming $4 \mathrm{~m}$ gap between buildings (Option 2), (c) assuming 6 $\mathrm{m}$ gap between buildings (Option 3), and (d) assuming same volume and uniform geometry (Option 4).

\subsection{EMISSIONS CHARACTERISATION}

The main emission source in the selected domain is the traffic running on this road. $\mathrm{PM}_{10}$ emissions were calculated using ADMS-Urban model, considering the mean traffic number of vehicles in rush hours as the baseline scenario for the traffic emissions. The emission factors for traffic from ADMS-Urban for the year of 2010 were considered appropriate for this type of road in Portugal. The following inputs were provided to the model for emission estimates: total number of vehicles per hour in the street canyon, vehicle types (LDV, HDV, buses and motorcycle) and average vehicle speed $\left(50 \mathrm{~km} \mathrm{~h}^{-1}\right)$, street width, canyon length, terrain type (urban), as well as average dimensions of the buildings. No other important sources of emissions were identified in the domain, so the only other values contributing for the $\mathrm{PM}_{10}$ concentration were the background concentrations. The background $\mathrm{PM}_{10}$ concentrations were considered as $20 \mu \mathrm{g} \mathrm{m}^{-3}$; these were adopted from the Portuguese Air Quality Station (Fidalguinhos station), which is classified as urban background station for this area.

\subsection{MEASUREMENTS OF PM PM $_{10}$ CONCENTRATIONS}

$\mathrm{PM}_{10}$ concentrations were measured during a field campaign, performed at Avenida do Bocage street, from 17-20 October 2011 during the day time between $0900 \mathrm{~h}$ and $1800 \mathrm{~h}$ (local time). The DustTrack model 8520 was used for the $\mathrm{PM}_{10}$ measurements. The sampler uses a suction pump to take the flow of $1.7 \mathrm{~L} \mathrm{~min}^{-1}$ through an optical chamber where the sample is backlighted with a laser beam and the particles reflect this light that is read by a photo detector. The detection circuit converts the light into voltage that is proportional to the mass concentration of $\mathrm{PM}_{10}$. Measurements were made at 7 different points that were $1.5 \mathrm{~m}$ above the ground level along the canyon length to gain the representative values. Fig. 4 shows the sampling locations. Summary of hourly average measured $\mathrm{PM}_{10}$ concentrations is provided in Table 1. Meteorological data was provided by the Instituto de Meteorologia. The average ambient temperature and relative humidity during the measurement campaigns were $25^{\circ} \mathrm{C}$ and $40 \%$, respectively. Predominant wind direction was noted as 'west' (i.e. along the street canyon).

\section{RESULTS AND DISCUSSION}

\subsection{THE BASE CASE}

Fig. 4 shows the simulated results for $\mathrm{PM}_{10}$ concentrations for the actual street configuration (Option 1) under four different wind directions (west, north, south and east). The figure shows contour plots of $\mathrm{PM}_{10}$ concentrations at $1.5 \mathrm{~m}$ above the road level. This is a typical human breathing height for exposure (WHO, 2010). Only $\mathrm{PM}_{10}$ emissions from the traffic are considered for computations and no background concentrations are added in this case. 
Garcia, J., Cerdeira, R., Tavares, N., Coelho, L.M.R., Kumar, P., Carvalho, M.G., 2013. Influence of virtual changes in building configurations of a real street canyon on the dispersion of $\mathrm{PM}_{10}$. Urban Climate 5, 68-81. http://dx.doi.org/10.1016/j.uclim.2013.08.002

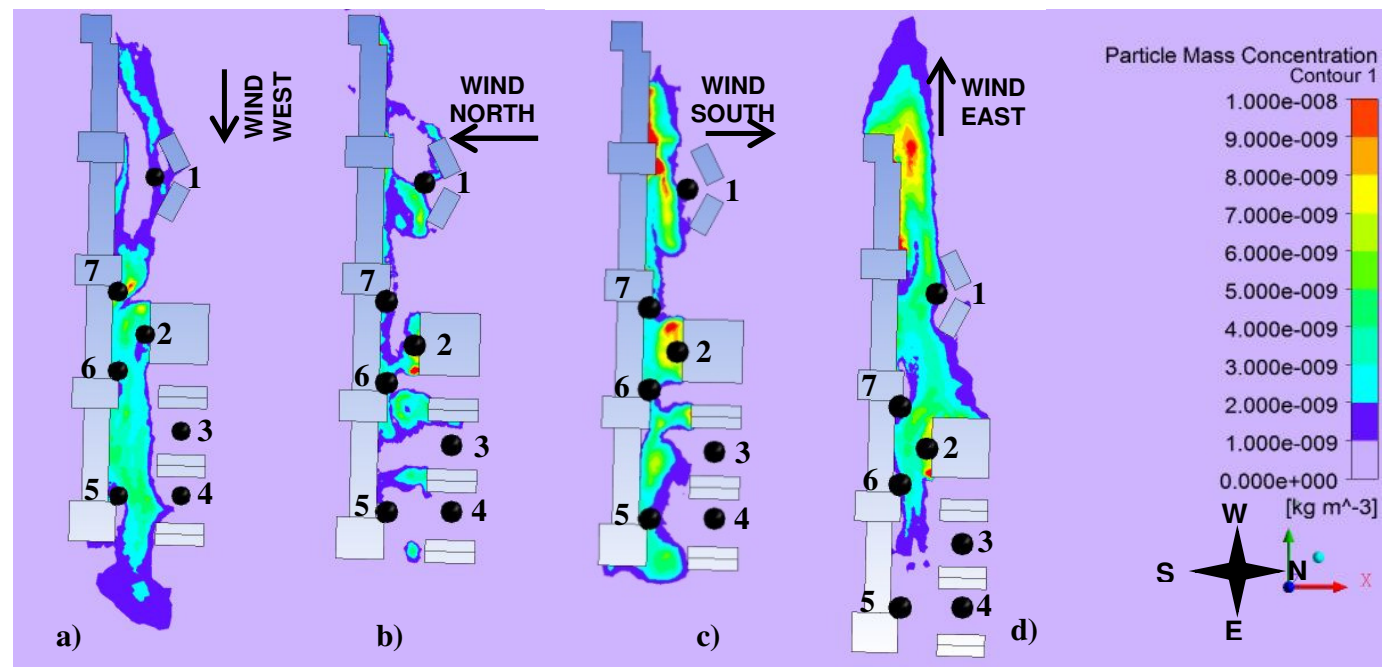

Fig. 4. Contour plots of $\mathrm{PM}_{10}$ concentrations at $1.5 \mathrm{~m}$ above the road level for the actual street configuration (i.e., Option 1) under the studied four main wind directions.

It is evident from the Fig. 4 that the highest values of $\mathrm{PM}_{10}$ concentrations are obtained for the conditions when the wind is coming from the south (cross canyon) and east (along canyon). The hot-spots (i.e. the locations with the highest concentrations) are appearing at the centre and at the end of the street. In the case of winds from the south, this hot-spot appears as a result of the vortex induced by the relatively tall building located at the middle of the street. In the case of winds from the east, the hot-spot can be seen in the beginning of the street due to the limited dispersion of $\mathrm{PM}_{10}$ and at the end of the street due to the accumulation of the particle concentration along the street.

Table 1 shows the values of modelled $\mathrm{PM}_{10}$ concentrations at $1.5 \mathrm{~m}$ height above the road level, including both traffic and background contributions for 'Option 1'. Measured $\mathrm{PM}_{10}$ concentrations and the Weighted Average Concentrations (WAC) are also reported at all the 7 measurements points located in the street canyon (Fig. 4). The WAC is estimated using the Eq. (4) which is the mean concentration weighted by the wind direction frequency $\left(f_{\mathrm{i}}\right)$ i.e., the average number of times in each year, each of the four directions are observed. This allows evaluating the particle concentration for the whole year, considering all the different wind directions.

$$
W A C=P M_{10} \times f_{i}
$$


Garcia, J., Cerdeira, R., Tavares, N., Coelho, L.M.R., Kumar, P., Carvalho, M.G., 2013. Influence of virtual changes in building configurations of a real street canyon on the dispersion of $\mathrm{PM}_{10}$. Urban Climate 5, 68-81. http://dx.doi.org/10.1016/j.uclim.2013.08.002

Table 1.PM $\mathrm{PM}_{10}$ concentrations at $1.5 \mathrm{~m}$ high for Option 1 (actual configuration)

\begin{tabular}{|c|c|c|c|c|c|c|c|}
\hline Designation & Location & $\begin{array}{c}\mathrm{PM}_{10} \text { Conc. } \\
\left(\mu \mathrm{g} \mathrm{m}^{-3}\right) \\
\text { west wind }\end{array}$ & $\begin{array}{c}\mathrm{PM}_{10} \text { Conc. } \\
\left(\mu \mathrm{g} \mathrm{m}^{-3}\right) \\
\text { north wind }\end{array}$ & $\begin{array}{c}\mathrm{PM}_{10} \text { Conc. } \\
\left(\mu \mathrm{g} \mathrm{m}^{-3}\right) \\
\text { south wind }\end{array}$ & $\begin{array}{c}\mathrm{PM}_{10} \text { Conc. } \\
\left(\mu \mathrm{g} \mathrm{m}^{-3}\right) \\
\text { east wind }\end{array}$ & $\begin{array}{c}\text { PM }_{10} \text { Measured } \\
\text { Conc. }\left(\mu \mathrm{g} \mathrm{m}^{-3}\right) \\
\text { west wind }\end{array}$ & $\begin{array}{c}\text { WAC } \\
\left(\mu \mathrm{g} \mathrm{m}^{-3}\right)\end{array}$ \\
\hline Point 1 & School & 21.6 & 21.2 & 20.7 & 22.3 & 33.0 & 21.3 \\
\hline Point 2 & Bingo & 23.0 & 28.6 & 27.1 & 27.0 & 31.0 & 25.4 \\
\hline Point 3 & Car park(border) & 20.1 & 20.0 & 20.1 & 20.0 & 29.0 & 20.1 \\
\hline Point 4 & Car park (middle) & 20.4 & 20.0 & 20.1 & 20.0 & 29.0 & 20.2 \\
\hline Point 5 & High building corner & 20.5 & 20.6 & 22.7 & 20.0 & 27.0 & 20.9 \\
\hline Point 6 & Residential building (east) & 22.2 & 21.5 & 21.9 & 21.0 & 28.0 & 21.7 \\
\hline Point 7 & Residential building (west) & 25.0 & 20.9 & 22.5 & 20.7 & 28.0 & 22.8 \\
\hline Mean value & For the 7 points & 21.8 & 21,8 & 22.1 & 21.6 & 29,3 & 21.8 \\
\hline $\begin{array}{l}\text { Standard } \\
\text { deviation }\end{array}$ & For the 7 points & 1.75 & 3.04 & 2.66 & 2.53 & 2.06 & 1.85 \\
\hline Mean value & $1.5 \mathrm{~m}$ plane (all domain) & 20.8 & 20.5 & 21.0 & 21.1 & $\begin{array}{ll}--- \\
--\end{array}$ & 20.8 \\
\hline
\end{tabular}

The highest modelled $\mathrm{PM}_{10}$ concentrations are found at Point 2 (Bingo building) with a value of $28.6 \mu \mathrm{g} \mathrm{m}^{-3}$ during the winds from the north. This point is located on the north end of the road near the largest building on this side, making difficult for the upstream wind to carry the pollutant outside the street. This point also shows one of the highest measured values. If we average the modelled $\mathrm{PM}_{10}$ concentrations over the all 7 points for each wind directions separately, the highest concentration $\left(22.1 \mu \mathrm{g} \mathrm{m}^{-3}\right)$ comes out for southerly wind conditions. Considering the mean values at $1.5 \mathrm{~m}$ high plane, the highest measured value for easterly wind conditions was noted as $21.1 \mu \mathrm{g} \mathrm{m}^{-3}$. Modelled results in Table 1 show that the average concentrations varied modestly at sampling points, except a few showing larger differences. For instance, the highest and the lowest modelled concentrations are $28.6 \mu \mathrm{g} \mathrm{m}^{-3}$ and $20.0 \mu \mathrm{g}$ $\mathrm{m}^{-3}$. They both are however below the daily mean and annual national limits for $\mathrm{PM}_{10}$ in Portugal, which are 50 and $40 \mu \mathrm{g} \mathrm{m}^{-3}$, respectively.

The WAC is important to study the weight of most frequent conditions. For example, the calculated value at point 1 is the $2^{\text {nd }}$ highest for the easterly winds. However, when this value is weighed with the wind direction, the concentration values become the $4^{\text {th }}$ highest. The differences in the WAC for average values across the street are not significant. However, comparison of individual points show important differences, indicating minimum and maximum values at Points 3 and 2 as 20.1 and $25.4 \mu \mathrm{g} \mathrm{m}^{-3}$, respectively.

Fig. 5 shows the measured and modelled concentrations of $\mathrm{PM}_{10}$ at $1.5 \mathrm{~m}$ above the road level. These values are reasonably close to each other but the CFD results show a slight under prediction at a few points 1 and 7. Point 1 and 7 are located near traffic lights and simulations does not take into account the start-stop or accelerating/decelerating speed conditions of vehicles - these could be the possible reasons for the increase in local $\mathrm{PM}_{10}$ emission rates and hence the difference in results. 
Garcia, J., Cerdeira, R., Tavares, N., Coelho, L.M.R., Kumar, P., Carvalho, M.G., 2013. Influence of virtual changes in building configurations of a real street canyon on the dispersion of $\mathrm{PM}_{10}$. Urban Climate 5, 68-81. http://dx.doi.org/10.1016/j.uclim.2013.08.002

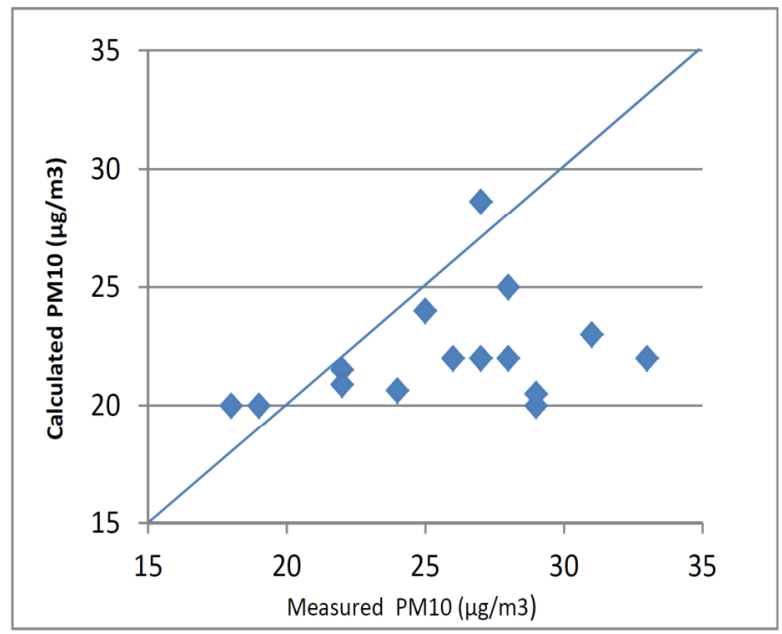

Fig. 5.Measured vs. modelled $\mathrm{PM}_{10}$ concentrations at points 1 to 7.

\subsection{PM $_{10}$ CONCENTRATIONS IN VIRTUAL CONFIGURATIONS}

Figs. 6, 7 and 8 show the $\mathrm{PM}_{10}$ contour plots at $1.5 \mathrm{~m}$ above the road level due to traffic emissions (without the background) for the three virtual Options 1, 2 and 3, respectively. Each figure shows four sub-figures and each sub-figure represents the concentration contours for west, north, south, and east wind directions, respectively.

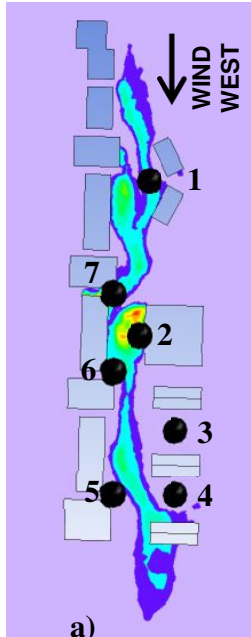

a)

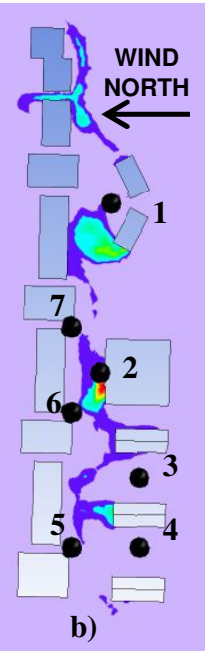

b)

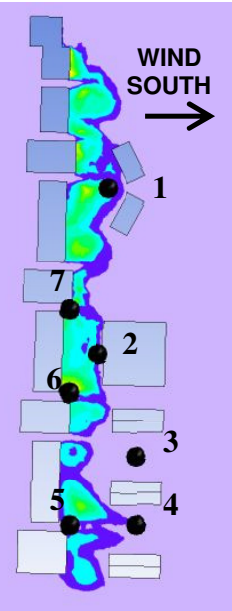

c)

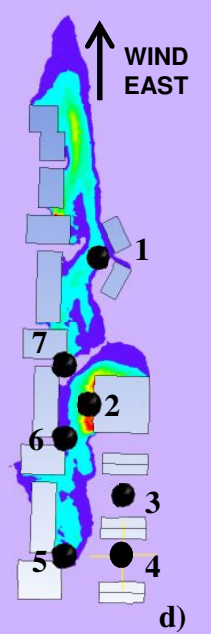

d)

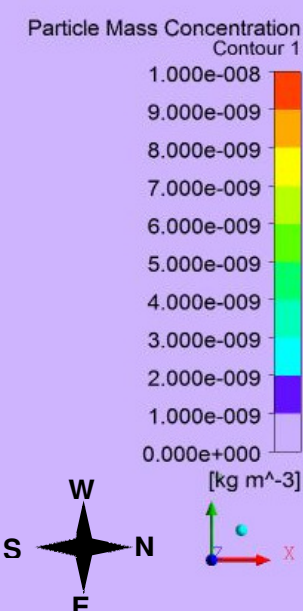

E

Fig. 6. Contour plots of $\mathrm{PM}_{10}$ concentrations at $1.5 \mathrm{~m}$ above the road level for the Option 2 under the wind directions.

It is possible to observe from the Fig. 6 that north (Fig. 6b) and south (Fig. 6c) winds promote the best and the worst pollutant dispersion for this configuration. This configuration includes a $4 \mathrm{~m}$ wide gap between buildings, which has decreased the concentrations of $\mathrm{PM}_{10}$ in the street in comparison with the concentrations observed in real street canyon (Fig. 4). These gaps promote the wind flows through them and carry the emitted pollutants outside of the street. These findings are in accordance to those reported by Chan et al. (2003). They investigated the pollutant dispersion characteristics in a three-dimensional simulation of an urban street canyon for various building array geometries. They found that the cross-road introduces a horizontal path for the pollutants to disperse away, resulting in overall reduction in retention values, as compared with a continuous canyon. 
Garcia, J., Cerdeira, R., Tavares, N., Coelho, L.M.R., Kumar, P., Carvalho, M.G., 2013. Influence of virtual changes in building configurations of a real street canyon on the dispersion of $\mathrm{PM}_{10}$. Urban Climate 5, 68-81. http://dx.doi.org/10.1016/j.uclim.2013.08.002

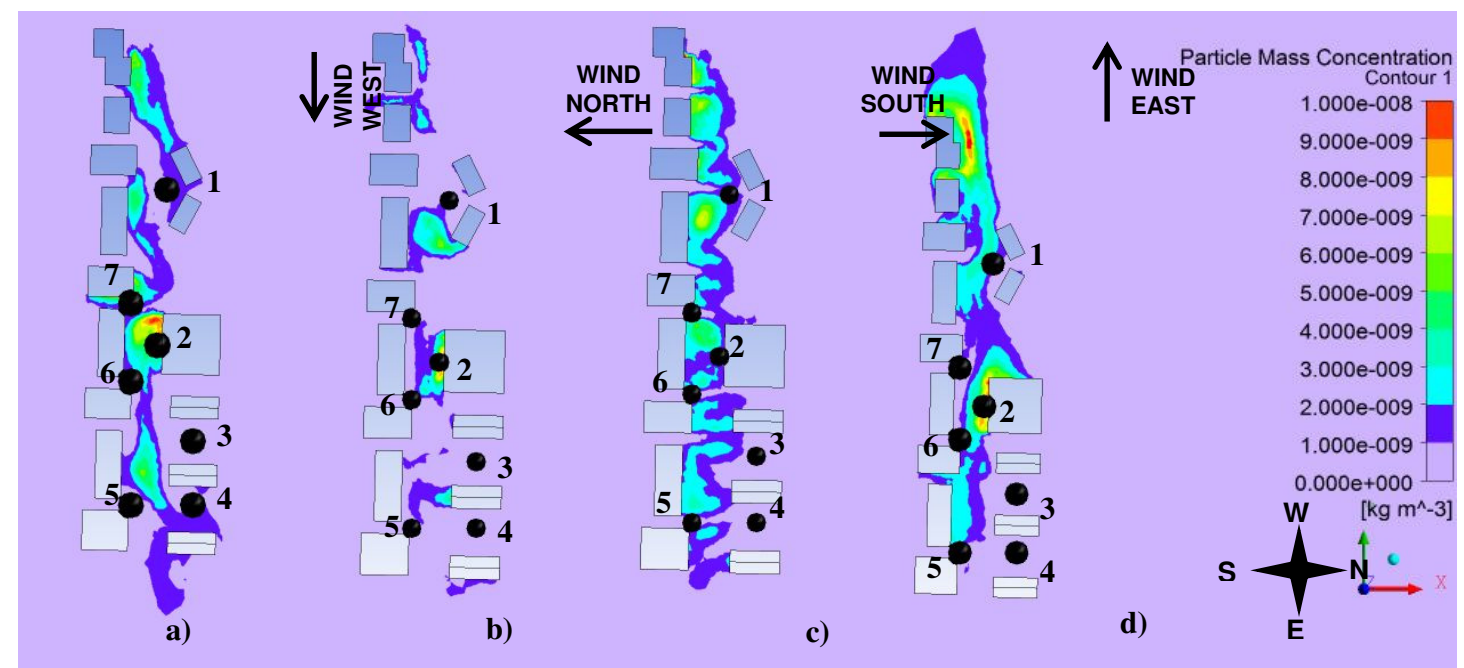

Fig. 7. Contour plots of $\mathrm{PM}_{10}$ concentrations at $1.5 \mathrm{~m}$ above the road level for the 'Option 3' under the four wind directions

Fig. 7 shows the $\mathrm{PM}_{10}$ contour plots for the 'Option 3' that assumes a $6 \mathrm{~m}$ wide gap between the buildings compared with $4 \mathrm{~m}$ wide gap in 'Option 2'. Comparison of Figs. 6 and 7 show similar distributions of $\mathrm{PM}_{10}$ concentrations. However some local differences can appear due to different air flow acceleration through the gaps (Table 2). This means that small differences in the gap size does not produce significant differences in the average $\mathrm{PM}_{10}$ concentration, but can cause significant local differences due the local eddies. These eddies, in general, allow higher particle dispersion but these can increase the retention time at some points, particularly for easterly wind. This effect can be observed in the Figs. 6 and 7 on the side of downwind building for easterly winds.

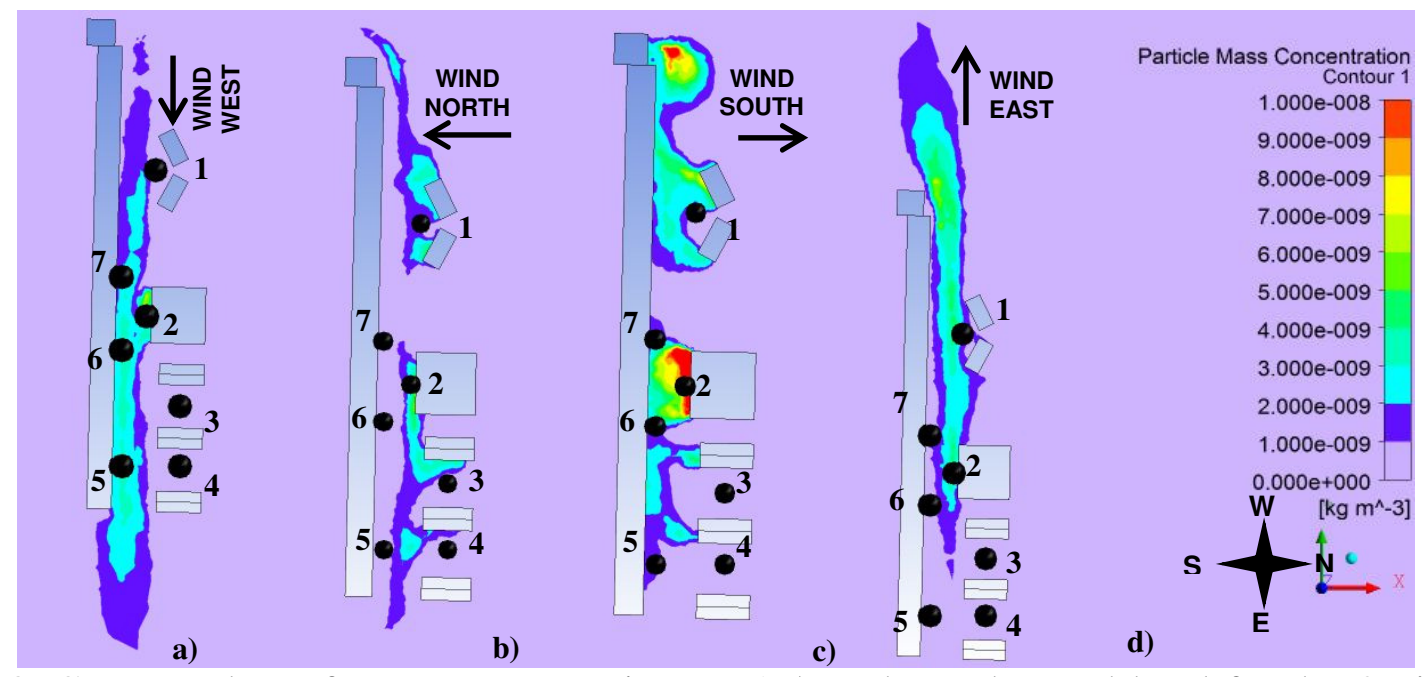

Fig. 8. Contour plots of $\mathrm{PM}_{10}$ concentrations at $1.5 \mathrm{~m}$ above the road level for the Option 4 under the four main wind directions.

By looking at the Fig. 8 (Option 4), it is possible to observe that for along-canyon wind directions, the dispersion of $\mathrm{PM}_{10}$ is promoted when all buildings have the same side cross width, allowing a good sweep by the wind in the street (Table 2). 
Garcia, J., Cerdeira, R., Tavares, N., Coelho, L.M.R., Kumar, P., Carvalho, M.G., 2013. Influence of virtual changes in building configurations of a real street canyon on the dispersion of $\mathrm{PM}_{10}$. Urban Climate 5, 68-81. http://dx.doi.org/10.1016/j.uclim.2013.08.002

Table 2. $\mathrm{PM}_{10}$ concentrations at $1.5 \mathrm{~m}$ above the road level for Options 1, 2, 3 and 4.

\begin{tabular}{|c|c|c|c|c|c|c|c|c|c|c|c|c|c|c|c|c|}
\hline \multirow[t]{2}{*}{ Designation } & \multicolumn{4}{|c|}{$\begin{array}{c}\text { PM }_{10} \text { Conc. } \\
\left(\mu \mathrm{g} / \mathrm{m}^{3}\right) \\
\text { west wind }\end{array}$} & \multicolumn{4}{|c|}{$\begin{array}{c}\text { PM }_{10} \text { Conc. } \\
\left(\mu \mathrm{g} / \mathrm{m}^{3}\right) \\
\text { north wind }\end{array}$} & \multicolumn{4}{|c|}{$\begin{array}{c}\text { PM }_{10} \text { Conc. } \\
\left(\mu \mathrm{g} / \mathrm{m}^{3}\right) \\
\text { south wind }\end{array}$} & \multicolumn{4}{|c|}{$\begin{array}{c}\mathrm{PM}_{10} \text { Conc. } \\
\left(\mu \mathrm{g} / \mathrm{m}^{3}\right) \\
\text { east wind }\end{array}$} \\
\hline & 1 & 2 & 3 & 4 & 1 & 2 & 3 & 4 & 1 & 2 & 3 & 4 & 1 & 2 & 3 & 4 \\
\hline Point 1 & 21.6 & 22.3 & 20.9 & 20.0 & 21.2 & 20.8 & 20.8 & 21.3 & 20.7 & 22.7 & 21.0 & 21.5 & 22.3 & 22.2 & 21.2 & 22.0 \\
\hline Point 2 & 23.0 & 25.7 & 25.9 & 24.1 & 28.6 & 23.2 & 26.8 & 22.8 & 27.1 & 21.8 & 21.1 & 30.7 & 27.0 & 27.6 & 26.8 & 23.0 \\
\hline Point 3 & 20.1 & 20.0 & 20.0 & 20.0 & 20.0 & 20.0 & 20.0 & 20.1 & 20.1 & 20.0 & 20.3 & 20.0 & 20.0 & 20.0 & 20.0 & 20.0 \\
\hline Point 4 & 20.4 & 20.0 & 20.4 & 20.0 & 20.0 & 20.0 & 20.0 & 20.2 & 20.1 & 20.7 & 20.5 & 20.6 & 20.0 & 20.0 & 20.0 & 20.0 \\
\hline Point 5 & 20.5 & 20.0 & 20.0 & 23.2 & 20.6 & 20.0 & 20.0 & 20.4 & 22.7 & 20.4 & 20.1 & 21.1 & 20.0 & 21.2 & 20.1 & 20.1 \\
\hline Point 6 & 22.2 & 21.0 & 20.1 & 23.3 & 21.5 & 20.1 & 20.1 & 20.0 & 21.9 & 23.9 & 20.2 & 21.9 & 21.0 & 20.7 & 20.5 & 20.4 \\
\hline Point 7 & 25.0 & 23.3 & 22.9 & 22.2 & 20.9 & 20.0 & 22.9 & 22.2 & 22.5 & 21.2 & 20.0 & 21.4 & 20.7 & 20.0 & 20.1 & 20.7 \\
\hline $\begin{array}{l}\text { Mean value } \\
(1.5 \mathrm{~m} \text { plane })\end{array}$ & 20.8 & 20.6 & 20.6 & 20.4 & 20.5 & 20.4 & 20.4 & 20.4 & 21.0 & 20.6 & 20.6 & 20.8 & 21.1 & 20.9 & 20.9 & 20.6 \\
\hline
\end{tabular}

Results in Table 2 for Option 4 show that at hot spot point 2, $\mathrm{PM}_{10}$ concentrations decay from $30.8 \mu \mathrm{g} \mathrm{m}^{-3}$ for south (cross-canyon) wind to $23.0 \mu \mathrm{g} \mathrm{m}^{-3}$ for east (along-canyon) due to channelling of flow, representing $\sim 23 \%$ lower $\mathrm{PM}_{10}$ concentrations. For the same hot spot point 2, under south (cross-canyon) wind, the $\mathrm{PM}_{10}$ concentrations decay from $27.1 \mu \mathrm{g} \mathrm{m}^{-3}$ (Option A) to $21.8 \mu \mathrm{g} \mathrm{m}^{-3}$ (Option B) and $21.1 \mu \mathrm{g} \mathrm{m}^{-3}$ (Option C) due to the introduction of gaps between buildings, representing a particle dilution of $\sim 20 \%$ and $\sim 22 \%$ for Options 2 and 3 , respectively, compared with the Option 1 .

\subsection{COMPARISON OF PM PM $_{10}$ MEAN CONCENTRATIONS OBTAINED FROM DIFFERENT CONFIGURATIONS}

The results of mean value of $\mathrm{PM}_{10}$ concentrations for a horizontal plane located at $1.5 \mathrm{~m}$ above the road level show that the configuration with different buildings size and no gap between them (option 1) generated the worst case having many points with increased concentrations (see Fig. 5 and Table 2). The implementation of gaps between buildings (options 2 and 3) promotes wind circulation crossing the street, improving pollutant removal for southerly (cross-canyon) wind directions (see Figs. 5, 6, 7 and 12). There is also an improvement in pollutant removal, mainly in areas with local recirculation near the gaps, compared with Option 1. Buildings with the same height (Option 4) seem to be a good configuration for along-canyon wind direction, since no local recirculation is promoted (Fig. 8).

For cross canyon wind directions, 'Option 4' shows a slight improvement in $\mathrm{PM}_{10}$ concentrations compared with 'Option 1' (Table 2). Comparison of Option 4 under southerly winds with Options 2 and 3 shows a slight increase of $\mathrm{PM}_{10}$ concentration, mainly because the air flow crossing the street is not promoted locally (Table 2). Chan et al. (2003) refers that urban variations in building height and breadth and intricate roof level configurations promote ventilation. Our results are in line with their findings that the combination of a uniform geometry in one side of the street with intricate geometry in the other side (Option 4) is the preferable solution for all wind direction, when mean values are considered (Table 2). The improvement in $\mathrm{PM}_{10}$ concentrations is modest for the cross-canyon winds and these findings are in agreement with the conclusions drawn by Chan et al. (2003).

Analysis of the different sampling points individually indicates the point 2 as a location with higher $\mathrm{PM}_{10}$ concentration (Table 2). It is possible to see that the highest values appear for the Options 1 and 4 under southerly winds (Fig. 9). This is because the downwind building has lower height compared with the upwind building that results in two set of vortex (i.e., main 


\section{Citation details:}

Garcia, J., Cerdeira, R., Tavares, N., Coelho, L.M.R., Kumar, P., Carvalho, M.G., 2013. Influence of virtual changes in building configurations of a real street canyon on the dispersion of $\mathrm{PM}_{10}$. Urban Climate 5, 68-81. http://dx.doi.org/10.1016/j.uclim.2013.08.002

and secondary). The secondary vortex is responsible for the increase in $\mathrm{PM}_{10}$ concentrations near the downwind building wall (see Figs. 9a and c). For the northerly winds, the upwind building has the lowest building height and the air flow promotes the pollutant dispersion in this case (Fig. 10). In Option 1, the effect of southerly wind direction is not noticed at point 2, because the buildings on both side of the street have the same height. This effect of building heights on pollutant dispersion is in accordance with the findings of Assimakopoulos et al. (2003). In Options 2 and 3, the difference in building height at point 2 is reduced, but the gaps promote lateral flows at the same time which reduces the pollutant concentration for southerly winds. This effect continues to be present during the northerly winds in comparison with Option 1, but the gaps do not produce any favourable effect when compared with Option 4 (Fig. 11). At the point 2 in Option 1, the different height of the buildings are on the side of the road that promotes three-dimensional effect on the air flow, which can only be observed by the 3D simulations (see Figs. 11 and 12).

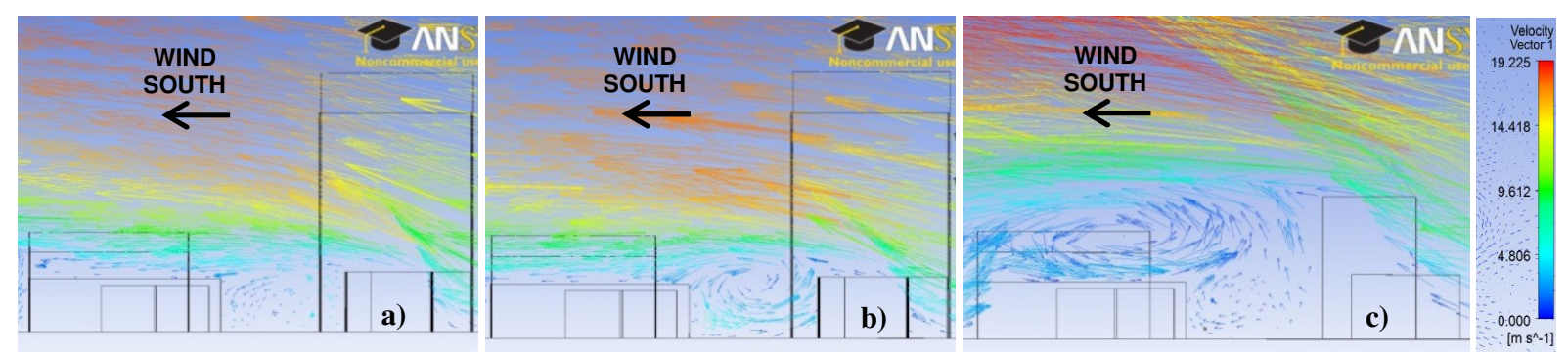

Fig. 9. Vertical plan of wind velocity vectors for south wind direction on point 2 for: (a) Option 1, (b) Option 3, and (c) Option 4.
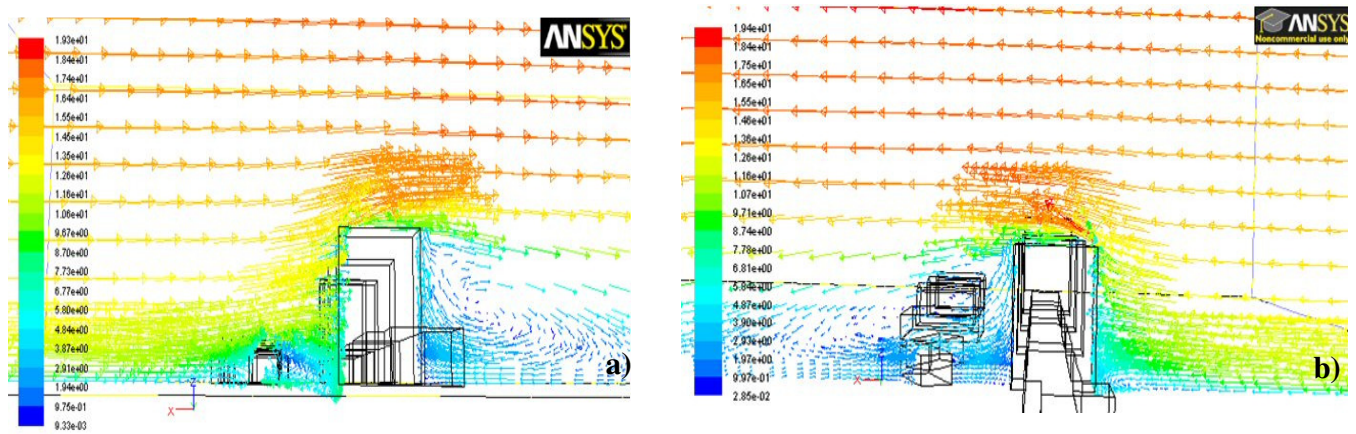

Fig. 10. Wind velocity vectors for south wind direction (a) and north wind direction (b) on point 2 for 'Option 1'.
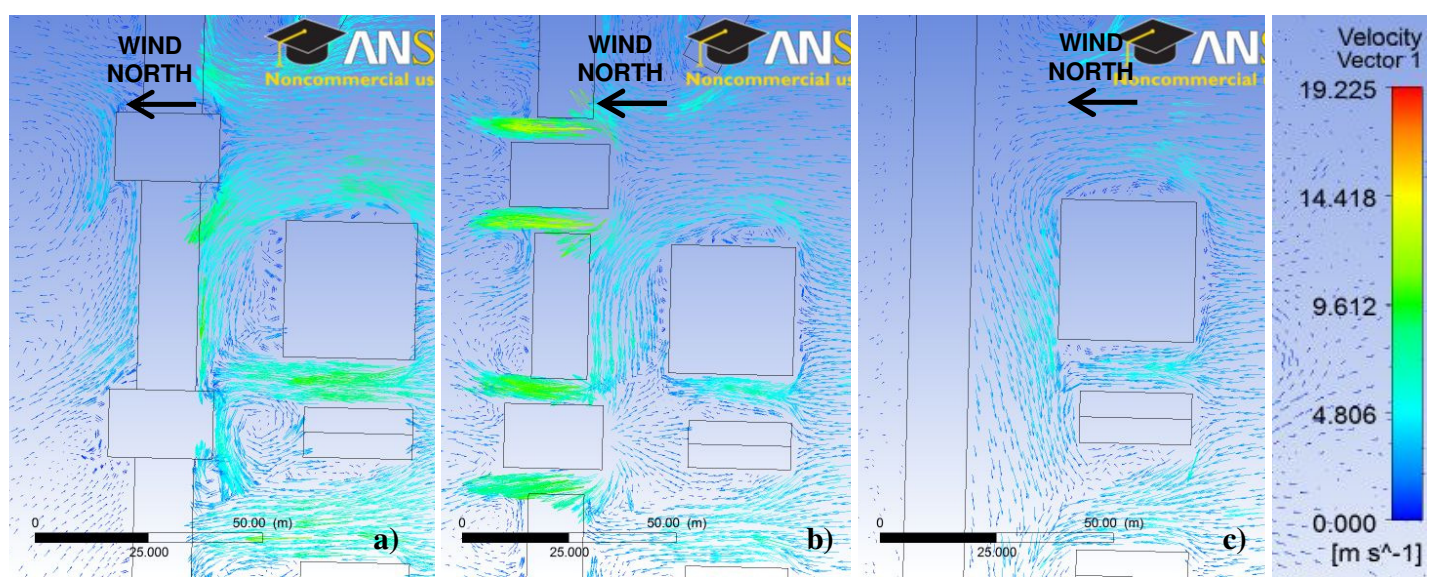
Garcia, J., Cerdeira, R., Tavares, N., Coelho, L.M.R., Kumar, P., Carvalho, M.G., 2013. Influence of virtual changes in building configurations of a real street canyon on the dispersion of $\mathrm{PM}_{10}$. Urban Climate 5, 68-81. http://dx.doi.org/10.1016/j.uclim.2013.08.002

Fig. 11. Horizontal plan of wind velocity vectors for north wind direction: (a) Option 1, (b) Option 3, (c) Option 4.
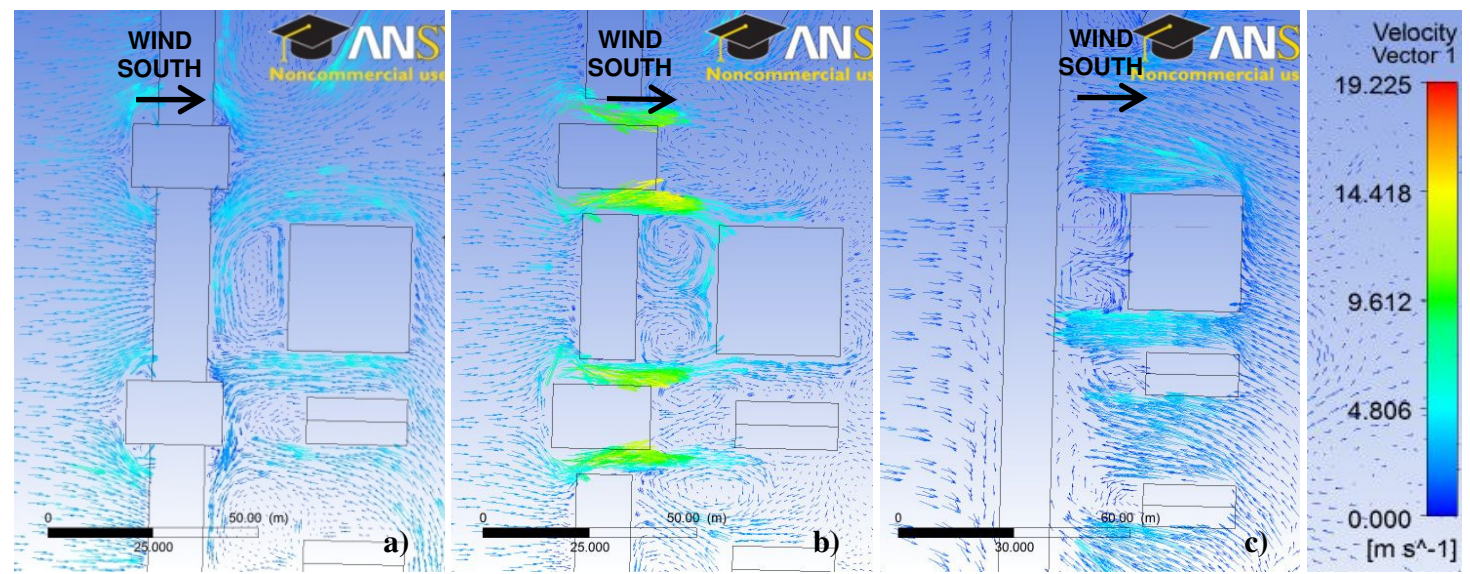

Fig. 12. Horizontal plan of wind velocity vectors for south wind direction: (a) Option 1, (b) Option 3, and (c) Option 4.

Table 3 shows the computed values of the WAC at $1.5 \mathrm{~m}$ above the road for the four different configurations chosen in this study. Generally, the results show better concentration values for Option 4 while the Option 1 presents the worst case. The WAC for $\mathrm{PM}_{10}$ values varies from $20.8 \mu \mathrm{g} \mathrm{m}^{-3}$ in the actual configuration (i.e., Option 1) to $20.4 \mu \mathrm{g} \mathrm{m}^{-3}$ for Option 4. The variation of WAC mean value for the horizontal plane is not very significant. However considering specific points showing the hot-spots, the location with the highest reduction (7\%) is point 7, showing a decrease from $22.8 \mu \mathrm{g} \mathrm{m}^{-3}$ for Option 1 to $21.2 \mu \mathrm{g} \mathrm{m}^{-3}$ for Option 2.

Table 3. The WAC values for Options 1, 2, 3 and 4 for all hot spots.

\begin{tabular}{|l|l|c|c|c|c|}
\hline Designation & \multicolumn{1}{|c|}{ Location } & Option 1 & Option 2 & Option 3 & Option 4 \\
\hline Point 1 & School & 21.3 & 21.8 & 20.8 & 20.8 \\
\hline Point 2 & Bingo & 25.4 & 24.1 & 24.9 & 24.7 \\
\hline Point 3 & Car park(border) & 20.1 & 20.0 & 20.1 & 20.0 \\
\hline Point 4 & Car park (middle) & 20.2 & 20.1 & 20.3 & 20.0 \\
\hline Point 5 & High building corner & 20.9 & 20.2 & 20.1 & 21.6 \\
\hline Point 6 & Residential building (east) & 21.7 & 21.2 & 21.2 & 21.8 \\
\hline Point 7 & Residential building (west) & 22.8 & 21.6 & 21.2 & 21.3 \\
\hline Mean value & 1.5m plane (all domain) & 20.8 & 20.5 & 20.6 & 20.4 \\
\hline
\end{tabular}

\section{SUMMARY AND CONCLUSIONS}

The CFD code FLUENT was used to simulate the dispersion of $\mathrm{PM}_{10}$ in a busy street canyon in Barreiro city, Portugal. Four different configurations of the street canyon, including the real street and three virtual scenarios after modifying the real street configurations are studied. The aims were to investigate the influence of changes in building configurations on the concentration levels of $\mathrm{PM}_{10}$ at various selected points located at a breathing height (i.e. 1.5 $\mathrm{m})$. The results indicate that changes in street configurations and building geometries have influenced the $\mathrm{PM}_{10}$ concentrations in the studied street canyon. It is also possible to reduce $\mathrm{PM}_{10}$ concentrations, and hence improve the air quality in a street canyon, after certain 
Garcia, J., Cerdeira, R., Tavares, N., Coelho, L.M.R., Kumar, P., Carvalho, M.G., 2013. Influence of virtual changes in building configurations of a real street canyon on the dispersion of $\mathrm{PM}_{10}$. Urban Climate 5, 68-81. http://dx.doi.org/10.1016/j.uclim.2013.08.002

alterations in the street configurations. Irrespective of street configurations, wind direction also plays a dominant role in the variation of $\mathrm{PM}_{10}$ concentrations. In general, the best average concentrations levels were observed for winds from the west and east (along canyon) directions for uniform geometry (Option 4). The formation of vortices at the corners of buildings was found to promote the trapping of pollutants at pedestrian level while the uniform buildings geometry with least corners helped in avoiding such formations. Gaps between the buildings (Options 2 and 3) during the cross-canyon winds, showed improved $\mathrm{PM}_{10}$ concentrations. For specific hot spots under cross-canyon wind conditions, $\mathrm{PM}_{10}$ concentrations decay $\sim 20 \%$ and $\sim 22 \%$ for Options 2 and 3 compared with Option 1, due to the introduction of gaps between buildings. Interestingly, when mean $\mathrm{PM}_{10}$ concentrations values are considered for all the planes located at $1.5 \mathrm{~m}$ above the road level, no significant improvements were noted with $6 \mathrm{~m}$ wider gaps between buildings compared with only $4 \mathrm{~m}$ gaps for the same wind directions. For along-canyon winds, buildings with uniform dimensions helped in avoiding some local trapping of pollutants at pedestrian level. Results show that for specific hot spots, $\mathrm{PM}_{10}$ concentrations decay $23 \%$ due to the channelling of flow, compared with those observed during the cross-canyon wind direction. The use of WAC was found to be a good measure to assess the influence of canyon configuration, because it takes into account the frequency of different wind directions. The findings of this work suggest that the building configuration plays an important role in affecting the overall and hot spot concentrations in street canyons.

\section{ACKNOWLEDGEMENTS}

The authors also wish to acknowledge the support from the Comissão de Coordenação e Desenvolvimento Regional de Lisboa e Vale do Tejo (CCDR-LVT) and Instituto de Metereologia for the meteorological data provided.

\section{REFERENCES}

Amorim, J.H., Lopes, M., Borrego, C., Tavares, R., Miranda, A.I., 2010. Air quality modelling as a tool for sustainable urban traffic management. Proceedings from the 18th International Conference on Modelling, Monitoring and Management of Air Pollution, WIT Transactions on Ecology and the Environment 136, 3-14

Ansys, 2009. ANSYS Fluent 12.0, Getting Started Guide. Fluent Guides

Assimakopoulosa, V.D., H.M ApSimon, H.M., Moussiopoulos, N., 2003. A numerical study of atmospheric pollutant dispersion in different two-dimensional street canyon configurations. Atmospheric Environment 37, 4037-4049.

Awasthi, S., Chaudhry, K.K, 2009. Numerical simulation and wind tunnel studies of pollution dispersion in an isolated street canyon. International Journal of Environment and Waste Management 4, 243-255.

Britter, R.E., Hanna, S.R., 2003. Flow and dispersion in urban areas. Annual Review of Fluid Mechanics 35, 469-496.

CERC, 2006. ADMS-Urban, an urban air quality management system. User guide -version 2.2 Cambridge, UK.

Chan, A.T., Au, W.T.W., So, E.S.P., 2003. Strategic guidelines for street canyon geometry to achieve sustainable street air quality-part II: multiple canopies and canyons. Atmospheric Environment 37, 2761-2772.

COST, 2007. Best practice guideline for the CFD simulation of flows in the urban environment, Quality assurance and improvement of microscale meteorological models, COST action 732. ISBN 3-00-018312-4. 
Garcia, J., Cerdeira, R., Tavares, N., Coelho, L.M.R., Kumar, P., Carvalho, M.G., 2013. Influence of virtual changes in building configurations of a real street canyon on the dispersion of $\mathrm{PM}_{10}$. Urban Climate 5, 68-81. http://dx.doi.org/10.1016/j.uclim.2013.08.002

De Paul, F.T., Sheih, C.M., 1986. A tracer study of dispersion in an urban street canyon. Atmospheric Environment 20, 455-459.

Di Sabatino, S., Buccolieri, S., Pulvirenti B, Britter, R., 2008. Flow and pollutant dispersion in street canyons using FLUENT and ADMS-Urban. Environmental Modelling and Assessment 13, 369-381.

EEA Technical report, No 12/2011.

EEA, 2011, Air quality in Europe - 2011 report, European Enviraonment Agency

Ehrhard, J., Khatib, I.A., Winkler, C., Kunz, R., Moussiopoulos, N., Ernst, G., 2000. The microscale model MIMO: development and assessment. Journal of Wind Engineering and Industrial Aerodynamics 85, 163-176.

FLUENT, 2009. User Manual:, Chapter 4. Turbulence, ANSYS, Inc.

Garcia, J., Coelho L., Gouveia C., Cerdeira, R., Louro, C., Ferreira T., Baptista, M., 2010. Analysis of human exposure to urban air quality in a children population. International Journal of Environment and Pollution 40, 94-108.

Heal, M.R., Kumar, P., Harrison, R.M., 2012. Particles, air quality, policy and health. Chemical Society Reviews 41, 6606-6630.

Holmes, N.S., Morawska, L., 2006. A review of dispersion modelling and its application to the dispersion of particles: An overview of different dispersion models available. Atmospheric Environment 40, 5902-5928.

Kumar, P., Morawska, L., 2013. Energy-pollution nexus for urban buildings. Environmental Science \& Technology 47, 7591-7592.

Kumar, P., Fennell, P., Langley, D., Britter, R., 2008. Pseudo-simultaneous measurements for the vertical variation of coarse, fine and ultra fine particles in an urban street canyon. Atmospheric Environment 42, 4304-4319.

Kumar, P., Garmory, A., Ketzel, M., Berkowicz, R., Britter, R., 2009. Comparative study of measured and modelled number concentrations of nanoparticles in an urban street canyon. Atmospheric Environment 43, 949-958.

Kumar, P., Gurjar, B.R., Nagpure, A., Harrison, R.M., 2011a. Preliminary estimates of nanoparticle number emissions from road vehicles in megacity Delhi and associated health impacts. Environmental Science and Technology 45, 5514-5521.

Kumar, P., Ketzel, M., Vardoulakis, S., Pirjola, L., Britter, R., 2011b. Dynamics and dispersion modelling of nanoparticles from road traffic in the urban atmospheric environment - a review. Journal of Aerosol Science 42, 580-603.

Kumar, P., Robins, A., Vardoulakis, S., Britter, R., 2010. A review of the characteristics of nanoparticles in the urban atmosphere and the prospects for developing regulatory controls. Atmospheric Environment 44, 5035-5052.

Martins, A., Cerqueira M., Ferreira F., Borrego C., Amorim J. H., 2009. Lisbon air quality: evaluating traffic hot-spots. International Journal Environment and Pollution 39, 306320.

Mochida A., Lizuka S., Tominaga Y., Yu-Fat Lun I., 2011. Up-scaling CWE models to include mesoscale meteorological influences. Journal of Wind Engineering and Industrial Aerodynamics 99, 187-198.

Nikolova, I., Janssen, S., Vos, P., Vrancken K., Mishra, V., Berghmans., P., 2011. Dispersion modelling of traffic induced ultrafine particles in a street canyon in Antwerp, Belgium and comparison with observations. Science of the Total Environment 412, 336-243.

Pospisil, J., Jicha, M., 2008. Determination of the PM10 urban threshold velocity of resuspension in an inner part of urban area. Croatian Meteorological Journal 43, 657661 
Garcia, J., Cerdeira, R., Tavares, N., Coelho, L.M.R., Kumar, P., Carvalho, M.G., 2013. Influence of virtual changes in building configurations of a real street canyon on the dispersion of $\mathrm{PM}_{10}$. Urban Climate 5, 68-81. http://dx.doi.org/10.1016/j.uclim.2013.08.002

Richards, P.J and Hoxey, R.P., 1993. Appropriate boundary conditions for computational wind engineering models using the $k-\varepsilon$ turbulence model, Journal of Wind Engineering and Industrial Aerodynamics 46, 145-153.

Sagrado, A., Beeck, J., Rambaud, P., Olivari, D., 2002. Numerical and experimental modelling of pollutant disperstion inside a street canyon. Journal of Wind Engineering and Industrial Aerodynamics 90, 321-339.

Santiago, J.L., Martín, F., 2008. SLP-2D: A new Lagrangian particle model to simulate pollutant dispersion in street canyons, Atmospheric Environment 42, 3927-3936.

Schatzmann, M., Leitl B., 2010, Validation of urban flow and dispersion CFD models, Proceedings of the Fifth International Symposium on Computational Wind Engineering (CWE2010), North Carolina, USA, May 23-27

Schlunzen et al., 1996. Hints for Using the Mesoscale Model 'METRAS'. Technical Report 6, Meteorologisches Institut der Universit" at Hamburg.

Vardoulakis, S., Fisher, B.E.A., Pericleous, K., Gonzalez-Flesca, N., 2003. Modelling air quality in street canyons: a review. Atmospheric Environment 37, 155-182.

Wang, P., Mu, H., 2010. Numerical simulation of pollutant flow and dispersion in different street layouts. International Journal of Environmental Studies 67, 155-167.

WHO, 2004. Outdoor air pollution: assessing the environment burden of disease at national and local levels.

WHO, 2010. WHO guidelines for indoor air quality: selected pollutants

Yassin, M., Kellnerová, R., Jaňour, Z, 2009. Numerical simulation on pollutant dispersion from vehicle exhaust in street configurations. Environmental Monitoring and Assessment 33, 257-273.

Zhou, Y., Levy, J., 2008. The impact of urban street canyons on population exposure to traffic-related primary pollutants. Atmospheric Environment 42, 3087-3098. 